Pesq. Vet. Bras. 35(2):173-176, fevereiro 2015 DOI: 10.1590/S0100-736X2015000200014

\title{
Celiotomy by plastrotomy in a yellow-footed tortoise (Geochelone denticulata) ${ }^{1}$
}

\begin{abstract}
Marcelo C. Rodrigues ${ }^{2 *}$, Wagner C. Lima², Ana M. Quessada ${ }^{2}$, Filipi A.N. Silva², Laís M.C. Silva ${ }^{2}$, André B. de Souza ${ }^{2}$, Charlys R.C. de Moura ${ }^{2}$ and Dayanne A.S.D. Lima ${ }^{2}$

ABSTRACT.- Rodrigues M.C., Lima W.C., Quessada A.M., Silva F.A.N., Silva L.M.C., Souza A.B., Moura C.R.C. \& Lima D.A.S.D. 2015. Celiotomy by plastrotomy in a yellow-footed tortoise (Geochelone denticulata). Pesquisa Veterinária Brasileira 35(2):173-176. Hospital Veterinário da Universidade Federal do Piauí, Centro de Ciências Agrárias, Campus Universitário, Teresina, PI 64049-550, Brazil. E-mail: olecramsopmac@yahoo.com.br

One herein reports a successful case of celiotomy by plastrotomy for removal of foreign bodies in yellow-footed tortoise (Geochelone denticulata). The animal was treated at the Veterinary Hospital of the Federal University of Piaui, with appetite loss, regurgitation, constipation, lethargy, reluctance to walk and slightly reddish ocular mucous membranes. Radiographic examination was performed, confirming the presence of foreign bodies in the stomach. The tortoise underwent celiotomy by plastrotomy for the removal of the foreign bodies. The opening of the plastron was performed through the abdominal shields, with the aid of a circular mini grinding saw. One performed an incision in the midline between the two abdominal veins to access the abdominal cavity. A gastrotomy for removal of the foreign bodies (nails, toothpicks, stones, pieces of plastic, glass and crockery pieces) was performed after the location of the stomach. The surgery was successful and confirmed with radiographic evaluation in the immediate postoperative period. The celiotomy by plastrotomy for removal of foreign bodies in that animal proved to be a viable, very important and safe technique to the survival of chelonians.
\end{abstract}

INDEX TERMS: Yellow-footed tortoise, Geochelone denticulata, gastric foreign body, chelonian, surgery, plastron.

\begin{abstract}
RESUMO.- [Celitomia por plastrotomia em jabuti-tinga (Geochelone denticulata).] Neste relato descreve-se um caso bem sucedido de celiotomia por plastrotomia para remoção de corpos estranhos em uma jabuti-tinga (Geochelone denticulata). 0 animal foi atendido no Hospital Veterinário da Universidade Federal do Piauí apresentando falta de apetite, regurgitação, constipação, letargia, relutância em andar e mucosas oculares hiperêmicas. Foi realizado exame radiográfico, o qual confirmou presença de corpos estranhos no estômago. 0 animal foi submetido à celiotomia por plastrotomia para remoção dos corpos estranhos. A abertura do plastrão foi realizada através dos escudos abdominais, com o auxílio de uma mini-serra circular de retífica. Foi feita uma incisão na linha média entre as duas
\end{abstract}

\footnotetext{
${ }^{1}$ Received on August 22, 2014.

Accepted for publication on December 29, 2014.

${ }^{2}$ Hospital Veterinário, Universidade Federal do Piauí, Centro de Ciências Agrárias, Campus Universitário, Teresina, PI 64049-550, Brazil. *Corresponding author: olecramsopmac@yahoo.com.br
}

veias abdominais para se acessar a cavidade abdominal e, uma vez exposto, o estômago foi incisado para remoção dos corpos estranhos (grampos, palitos de dente, pedras, peças de plástico, fragmentos de louças e vidros). A cirurgia foi bem sucedida e a remoção total dos corpos estranhos foi confirmada por radiografia realizada no pós-operatório imediato. A celiotomia por plastrotomia para remoção de corpos estranhos neste animal demonstrou ser uma técnica muito importante, segura e viável para a sobrevivência de quelônios.

TERMOS DE INDEXAÇÃO: Jabuti-tinga, Geochelone denticulata, corpo estranho gástrico, quelônio, cirurgia, plastrão.

\section{INTRODUCTION}

Tortoises, terrestrial chelonians highly sought after as pets are prone to infectious and parasitic diseases outbreaks in captivity due to environmental and hygienic conditions (Rosskopf Jr \& Shindo 2003). They are usually omnivores in the wild eating leaves, flowers, fruits, grass, invertebra- 
tes, carcasses and other foods they may find on the ground (Baptistotte \& Cubas 2006). Geophagy is a common habit for many chelonian species, which results in the ingestion of foreign bodies, lodged in the substrate (Matushima 2001). Those bodies may obstruct the gastrointestinal tract and lead them to death, or even damage the gastroenteric walls, reduce nutritional gain and increase intestinal transit (Bjorndal 1997, Oliveira et al. 2009).

The clinical signs of gastrointestinal disorders in the species, such as the ingestion of foreign bodies and intestinal obstruction or compression are anorexia, dehydration, lethargy, and body weight loss. The diagnosis is made by means of radiography or endoscopy (Matushima 2001).

In cases of gastrointestinal foreign bodies in chelonians, depending on the type of obstruction and clinical signs, the treatment may be conservative or surgical (Mas 2001).

Surgical interventions which access the coelomic cavity are common and may be performed by endoscopy through the prefemoral fossae (Pessoa et al. 2008) or a plastrotomy with a drill or a saw (Oliveira et al. 2009). However, an adequate, safe and easily reversible anesthetic protocol, capable to assure immobilization, analgesia and muscle relaxation is a sine qua non condition (Baptistotte \& Cubas 2006).

The present case report aims at contributing to the medical-surgical care of chelonians describing a successful case of removal of foreign bodies in a Yellow-Footed Tortoise (Geochelone denticulata) through celiotomy by plastrotomy.

\section{CASE REPORT}

An approximately eight year-old male yellow-footed tortoise weighting $5 \mathrm{~kg}$ was taken to the Veterinary Hospital at Federal University of Piauí. Its owner reported the animal lives on a small farm, eats whatsoever it is offered to it and had presented, about five days before the appointment, the following symptoms: pallor, loss of appetite, regurgitation and constipation. During the physical examination the animal showed apathy, reluctance to walk and its ocular mucous membranes were slightly reddish.

The animal was taken to the $x$-ray room and its radiography was performed with the animal in dorsoventral position. Dorsoventral radiography showed detected distention of intestinal loops and the presence of radiopaque material in the stomach (Fig.1). No evidence of peritonitis and/or perforation was observed.

The initial treatment was carried through the conservative approach: fluid therapy with $0.9 \%$ sodium chloride, intravenously, oral mineral oil dose $(2.0 \mathrm{ml}, \mathrm{BID})$, intramuscular (IM) anti-inflammatory (Flunixin Meglumine, $0.5 \mathrm{mg} / \mathrm{kg}$, Banamine, Schering-Plough, Brazil) and antibacterian chemoprophylaxis (metronidazol, 50mg/kg, oral, SID, União Química, Brazil).

After an unsuccessful five-day treatment the animal was taken to the operating room in order to be performed a celiotomy by plastrotomy for the removal of the foreign bodies.

The chelonian was placed in dorsal decubitus position and plastron antisepsis was performed with alcohol-iodine and chlorhexidine $1 \%$. The anesthetic plan was achieved through a combination of ketamine $(60 \mathrm{mg} / \mathrm{kg}$, IM, Quetamina, Vetnil, Brazil) and midazolam (2mg/kg, IM, Dormonid, Roche, Brazil).

Fluid therapy was kept during the trans-surgical period with a $0.9 \%$ sodium chloride intravenous infusion through the jugular vein.

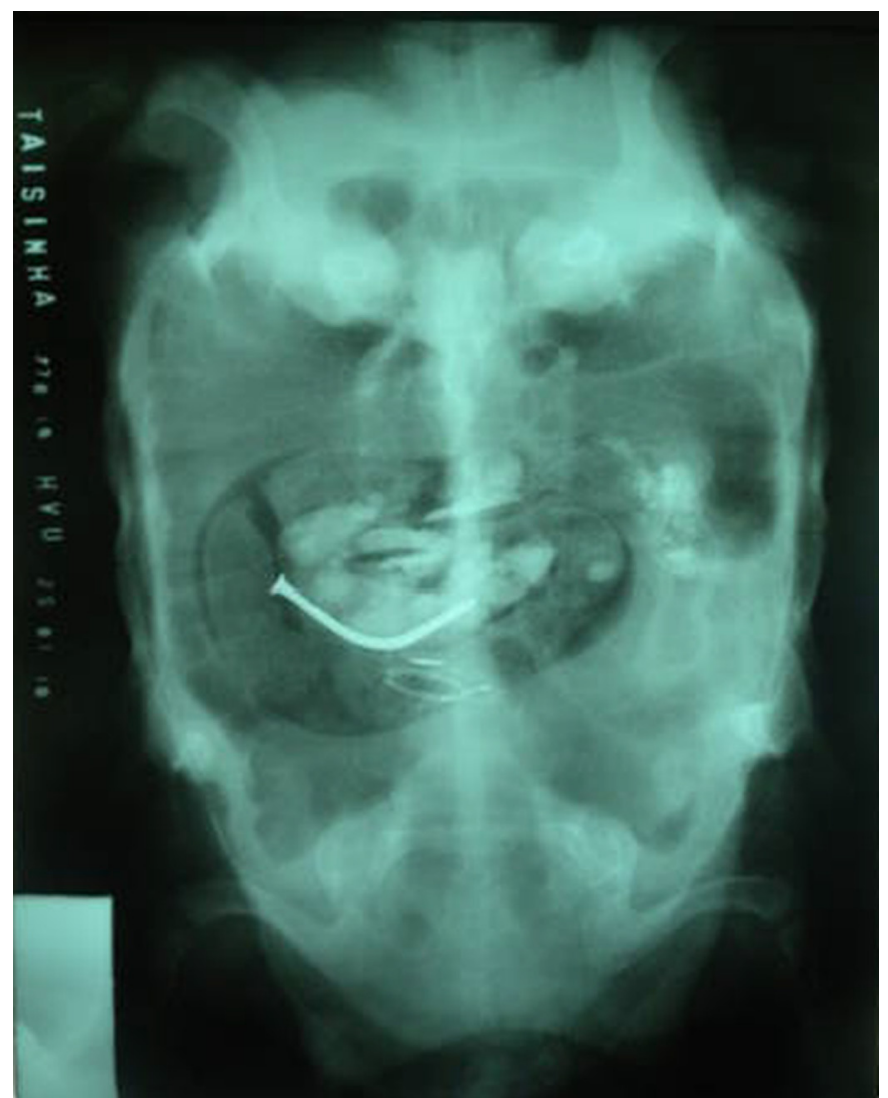

Fig.1. Radiography of the yellow-footed tortoise (Geochelone denticulata) showing distention of intestinal loops and the presence of radiopaque material in the stomach.

The opening of the plastron was performed through the abdominal shields by a circular mini grinding saw for home use. The incision was rectangular with a $45^{\circ}$ inclination. It was irrigated with saline during the plastron osteotomy. The fragment was raised by means of a periosteal elevator, separated from the muscle under the plastron and preserved in ringer lactate solution until its reimplantation.

A midline incision was performed between the two abdominal veins to access the abdominal cavity. After the location of the stomach, the gastrotomy was held for the extraction of quite diverse foreign bodies, like nails, toothpicks, stones, pieces of plastic, glass and crockery pieces (Fig.2). Soon after, one preceded the gastroraphy, performed in seromuscular pattern in two plans of suture, the first one simple separated and the following in continuous inverse pattern, both with 3-0 polyglactin 910 . The suture of the coelomic membrane was simple separated, with 3-0 polyglactin 910, and the fragment of the plastron was restored to its original position. After cleaning and degreasing the operative field with ether, one applied autopolymerizing acrylic resin for the protection and immobilization of the fragment (Fig.3).

The surgical procedure was successful, which was confirmed by the radiographic evaluation in the immediate postoperative period. The postoperative medication protocol consisted of meloxicam (0.1 mg / kg, IM, SID/3days, Maxicam, Ourofino, Brazil), doxycycline (10 mg / kg, IM, SID/6 days, doxiciclina, Vetnil, Brazil) and dietary treatment (leaves, fruits and eggs crushed in blender) supplied with the aid of a syringe. The animal was discharged 6 days after surgery, as soon as it started eating spontaneously.

At the last evaluation three months postoperatively, the animal was in excellent health. 


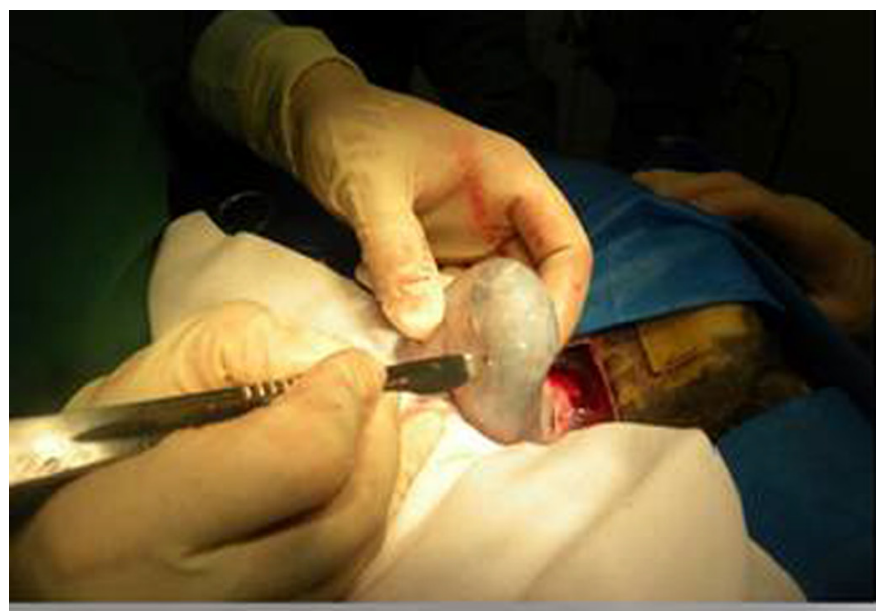

mals were contaminated with solid waste, which suggests that the amplitude of variation in the amount of foreign bodies found is directly related to their availability in the environment and/or the absence of food (Tourinho et al. 2008).

In most cases foreign bodies in the gastrointestinal tract of chelonians often occur in the stomach. Those bodies usually suffer fragmentation; increasing sub-lethal effects due to the increasing of the contact surface of the items with the gastrointestinal walls, resulting in a diminished capacity on nutrient uptake (Tourinho et al. 2008). The present case report confirmed all the above-cited observations, including pallor and apathy, which revealed malnutrition.

The clinical signs and the confirmation of the diagnosis by dorsi-ventral radiographic were enough to confirm the presence of foreign bodies, such as observed in a green tur-

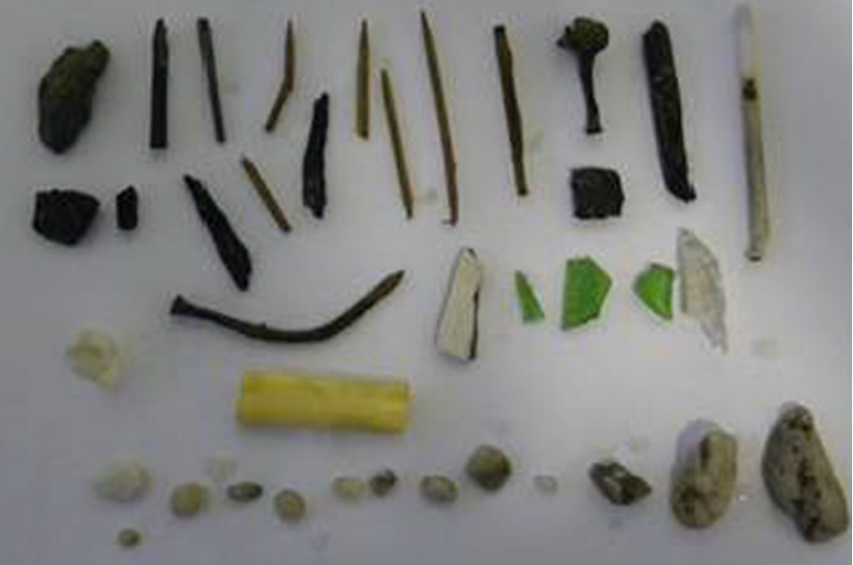

Fig.2. (A) Aperture of celomatic cavity of the yellow-footed tortoise (Geochelone denticulata) with exposure of the stomach and initial incision. (B) Diverse foreign bodies (nails, toothpicks, stones, pieces of plastic, glass and crockery

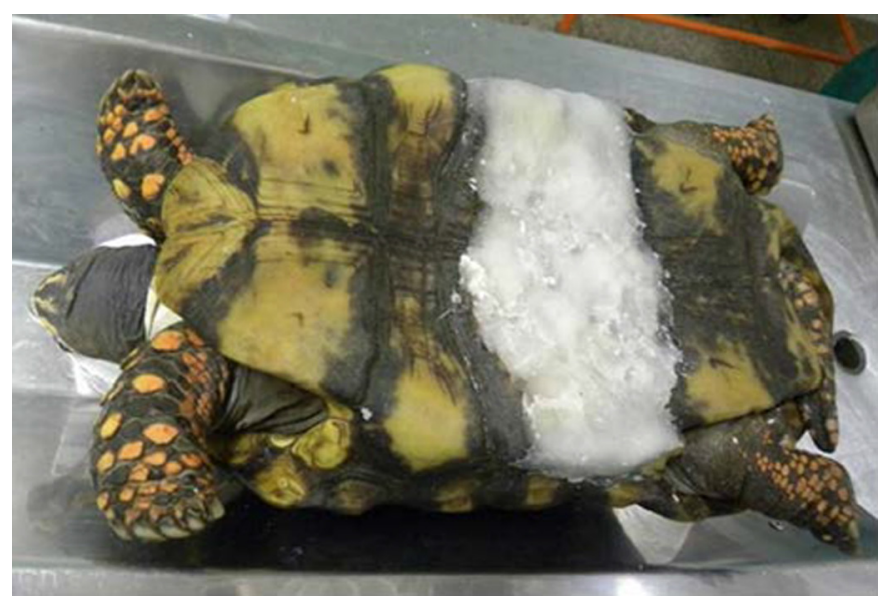

Fig.3. Final aspect of closing plastron with acrylic resin in yellow-footed tortoise (Geochelone denticulata) submitted to gastrotomy for removal foreign bodies.

\section{DISCUSSION AND CONCLUSION}

The poor nutrition and lack of regular cleaning of the area which the animal lives possibly has been the major cause for the ingestion of foreign bodies by chelonian. A study with sea turtles observed that $100 \%(n=29)$ of the anitle (Chelonia mydas) with intestinal obstruction (Helmick et al. 2000).

The literature diverges on the approach of gastrointestinal foreign bodies in turtles. Some authors suggest a conservative approach (natural elimination of foreign bodies), which was successful in sea-turtles (Mas 2001, Tourinho et al. 2008) and was therefore adopted in this case report. However, surgery was necessary once the first procedure was unsuccessful. Thus, the recommendation proposed by the literature is that surgical intervention must be immediately performed after the diagnosis of foreign body (Raphael 2003). Furthermore, the animal presented signs of toxemia, like apathy, reluctance to walk, and slightly reddish ocular mucous membranes, making surgery the most important option for the survival of the patient.

Regarding the anesthetic protocol in chelonians isoflurane is considered the most appropriate anesthetic, although a dissociative anesthetic such as ketamine may be used alone or combined with tranquilizers and analgesics (Baptistotte \& Cubas 2006). The protocol adopted in this case was sufficient to keep the turtle in anesthetic plan, allowing a safe surgery.

The coelomic cavity in chelonians may be accessed by celiotomy after the opening of the plastron, which was successfully used for removal of foreign bodies in a case of intestinal compactation in a D'Orbigny's slider turtle (Trachemys dorbignyi) (Oliveira et al. 2009) or by the prefemoral fossae, which was successful in performing laparoscopic oophorectomy in a red eared slider turtle (Trachemys scripta elegans) (Pessoa et al. 2008). In the case herein reported one decided on the celiotomy with plastron opening due to the lack of laparoscopy equipment at the hospital where the animal was taken to. Besides, the technique provides a better evaluation of the coelomic cavity (Miwa 2010). Although an invasive procedure with slow healing and rehabilitation (Oliveira et al. 2009), the option was efficient for the animal.

The oblique incision in the plastron was considered important because it prevented the fragment which was removed to dislocate and broke into the cavity after replacement (Baptistotte \& Cubas 2006). The procedure probably contributed to the satisfactory postoperative recovery observed in the tortoise. 
The autopolymerizing acrylic resin for the protection and immobilization of the fragment of the plastron is supported by the literature (Pachaly 1992) and presented good results, allowing the patient an excellent postoperative recovery.

One proved that the celiotomy by plastrotomy for the removal of gastrintestinal foreign bodies was a viable and safe technique for the survival of the chelonian.

\section{REFERENCES}

Baptistotte C. \& Cubas P.H. 2006. Chelonia (Tartaruga, cágado, jabuti), p.86-119. In: Cubas Z.S.J., Silva C.R. \& Catão-Dias J.L. (Eds), Tratado de Animais Selvagens. Roca, São Paulo.

Bjorndal K.A. 1997. Foraging ecology and nutrition of sea turtles, p.199231. In: Lutz P.L. \& Musick J.A. (Eds), The Biology of Sea Turtles. CRC Press, Florida.

Helmick K.E., Bennett R.A., Ginn P., Dimarco N., Beaver D.P. \& Dennis P.M. 2000. Intestinal volvulus and stricture associated with a leiomyoma in a green turtle (Chelonia mydas). J. Zoo Wildl. Med. 31:221-227.

Mas M. 2001. Chelonian noninfectious diseases, p.25-27. In: Fowler M.E. \& Cubas Z.S. (Eds), Biology, Medicine and Surgery of South America Wild Animals. Iowa State University Press, Ames.

Matushima E.R. 2001. Chelonian infectious diseases and general medicine, p.22-24. In: Fowler M.E. \& Cubas Z.S. (Eds), Biology, Medicine and
Surgery of South America Wild Animals. Iowa State University Press, Ames.

Miwa Y. 2010. Removal of urinary calculi via the cloaca in tortoises. Exotic 10:5-7.

Oliveira F.S., Delfini A., Martins L.L., Faria Jr D. \& Machado M.R.F. 2009. Obstrução intestinal em tigre d'água (Trachemys dorbignyi). Acta Scientiae Veterinariae 37:307-310. Available from <http://www.ufrgs.br/ actavet/37-3/PUB\%20849.pdf> Access on March 17, 2011.

Pachaly J.R. 1992. Doenças nutricionais das aves silvestres cativas, p.8081. In: Ibid. (Ed.), Medicina de Animais Selvagens, Apostila, Curitiba.

Pessoa C.A., Rodrigues M.A., Kozu F.O., Prazeres R.F. \& Fecchio R.S. 2008. Ooforectomia videoassistida por acesso pré-femural em tartaruga-de-ouvido-vermelho (Trachemys scripta elegans). Pesq. Vet. Bras. 28:345349. Available from <http://www.scielo.br/pdf/pvb/v28n7/v28n7a05. pdf $>$ Access on March 12, 2011

Raphael B.L. 2003. Chelonians (turtles, tortoises), p.48-58. In: Fowler M.E. \& Miller R.E. (Eds), Zoo and Wild Animal Medicine. 5th ed. Saunders Elsevier, St Louis., Missouri.

Rosskopf Jr W.J. \& Shindo M.K. 2003. Syndromes and conditions of commonly kept tortoise and turtle species. J. Exotic Pet Med.12:149-161.

Tourinho P.S., Ivar do Sul J.A. \& Fillmann G. 2008. Freqüência de ingestão e tipos de resíduos sólidos em tartarugas-verdes na costa do Rio Grande do Sul, Brasil: distribuição e fragmentação no trato gastrointestinal. III Congresso Brasileiro de Oceanografia - CBO'2008, I Congresso Ibero-Americano de Oceanografia - I CIAO, Fortaleza, CE. Available from <http://www.globalgarbage.org/0716.pdf> Access on February 1, 2011. 